UNIVERSITY OF CHITRAL JOURNAL OF LINGUISTICS AND LITERATURE

\title{
Towards a More Effective Second Language Writing Pedagogy: Using Task-based Reading to Develop Writing Skills of ESL Learners
}

\author{
Shazia Aziz \\ Assistant Professor of English, COMSATS University Islamabad, Lahore Campus \\ shazia.aziz@cuilahore.edu.pk \\ ORCID ID: https://orcid.org/0000-0001-9566-5053
}

\section{Amna Naveed}

Assistant Professor of English, COMSATS University Islamabad, Lahore Campus

ORCID ID: https://orcid.org/0000-0001-9886-1543

\section{Dr Mudassar M Ahmad}

Assistant Professor, English Language Department, (YEL \& PYI), Royal Commission Yanbu, Saudi Arabia

ORCID ID: https://orcid.org/0000-0002-5735-3558

\begin{abstract}
The connection between reading and writing has been acknowledged since long and explored through comprehension -based learning activities but not investigated substantially through empirical research into task-based reading activities. This study was carried out to explore the link between task-based reading activities and improvement in ESL writing. The study was prompted by the need to inculcate the maximum level of writing proficiency in a limited time available for instruction in a 4 month semester. We experimented introducing task-based critical reading to explore its impact on the ESL writing proficiency of Pakistani ESL learners at undergraduate level with Computer Science as their major. Analysing students' pre-test and post-test scores using Wilcoxon signed rank test and t test revealed a significant improvement in the overall writing proficiency, content, organization, sentence structure (SS), grammar, punctuation, and spelling (GPS) of students. The findings have important pedagogical implications for improving the learners' writing proficiency by integrating task-based reading activities in ESL teaching. The article also suggests some of the tasks that teachers can associate with reading in classrooms. It recommends making authentic reading material part of the ESL syllabus everywhere in the world in order to equip learners with better writing skills essential for success in all subjects, higher studies, and research.
\end{abstract}

Keywords: Task- based language learning; proficiency; motivation; schemata; fluency; process-oriented approach; second language writing development

\section{Introduction}

Pakistan is a multilingual country where around 73 regional languages (Rehman, 2019) are spoken and Urdu is the national language of the people of Pakistan. Hence, Urdu is taught throughout the country as a compulsory language during the first 
twelve years of education. Alongside, English is taught as a compulsory subject to students from primary to undergraduate level in Pakistani institutions and the content gradually increases in relevance to students' majors. Moreover, it is also a medium of instruction and the core language for research in all major areas including Engineering, Environmental Science, Media and Communication, Psychology, Sociology, and Business Studies, to name a few (excluding majors in other languages like Urdu, Punjabi, etc.) in higher education. Therefore, the Higher Education Commission of Pakistan has made it compulsory for universities to teach 3 to 4 courses in English during every undergraduate program that prepare students for academic and professional writing related to their areas along with improving their proficiency in all the four skills of English.

At COMSATS (Commission on Science and Technology for Sustainable Development in the South) University, students doing different majors are taught 3 to 4 of these courses: English Comprehension and Composition, Functional English, Technical Report Writing Skills, Writing and Presentation Skills, Communication Skills, Business Communication, and Communication Skills Workshop. However, many students enrolled with a low to average level of proficiency need to be given more input in the target language than permitted by the time allocated to a semester; the course contents; and the traditional, instruction-based teaching that is mainly teachercentred with teacher lecturing on how to write and what to write. Most of the students come from institutions that employ either grammar translation method or lecture method for teaching till intermediate level.

The benefits of task-based teaching and introducing reading activities have been found by many researchers in second language recently in experimental studies. Yundayani and Rafli (2018)contend that task-based instructional materials significantly improve students' writing skills for academic purposes by helping them overcome their difficulty in creating, developing and organizing ideas into a paragraph. Similarly, Kafipour, Mahmoudi, and Khojasteh (2018) propound that Task-Based approach is closely linked with Communicative Language Teaching (CLT), and hence it is characteristic of collaborative learning, learner centeredness, real-life interaction, and negotiation of meaning. They posit that it improves learners' writing skills in a regional 
medium milieu. Hosseinpour and Biria (2014)found that students working on collaborative tasks outperformed those working individually in content, vocabulary, grammar, and organization while writing. Shaheen, et. al (2019) proposed a pedagogical framework for intercultural classes having Pakistani and Afghan students in a Pakistani university based on Input-oriented approach in combination with Contextualized Task Based Language Teaching (CTBLT) for desired academic outputs in a diverse class.

This study set out to experiment the assumption that extensive reading coupled with task-based activities can cover up this gap and give students an ample amount of input in the limited time available in order to enable them to use the target language proficiently. Hence, this action research was carried out to investigate the impact of the implementation of task-based reading in an ESL classroom on the academic writing of undergraduate students studying the module English Comprehension and Composition at COMSATS University Islamabad, Lahore Campus.

Keeping these benefits in mind, this study was carried out throughout a semester to investigate its effects on the participating students' writing skills. Several task-based reading activities were introduced during the whole semester and the results of pre-test and post-test were analyzed using Wilcoxon signed rank test and t test to see its impact on the students' overall writing proficiency, content, organization, sentence structure (SS), grammar, punctuation and spelling (GPS).

Hence, the research questions investigated were:

Q1. Does the implementation of task-based reading improve students' writing performance in ESL?

Q2. If yes, which of the five elements viz. (1) content; (2) organization; (3) sentence structure;(4) diction; and (5) grammar, punctuation, spelling show a significant improvement?

\section{Literature Review}

ESL writing proficiency is a problem for many students in Pakistan where English is taught and learnt as a second language. Writing in a second or foreign language is the most difficult skill to learn, and in most situations, the most important one for language learners to acquire in academic contexts (Negari, 2011). Despite this, it has found little place in research and pedagogy so far, especially in the context of 
Pakistan. Ezza (2010) ascribes writing problems to employing outdated pedagogical resources and approaches.

ESL teachers have been practising different methods such as GTM, Direct method and most recently followed corrective feedback (to name a few) for teaching and improving students' writing. We believe that all these methods often compromised on the quantity of input at the disposal of students. Hence, a remarkable improvement was observed only in rare cases.

Research on the efficacy of different methods of foreign or second language teaching have reached different findings.Negari (2011), for example, concludes in one of the studies that the instruction of concept mapping strategy has a positive effect on EFL learners' writing achievements. Whereas, de Carvalho and Briglia (2013) declare the concept of literacy as a basic element of foreign language teaching. However, the findings of Huang and Bailey (2016) reveal that instruction and reading strategies are important factors in determining long-term literacy outcomes. Although writing practice accompanied with written feedback is considered effective and sufficient for the improvement of students' writing by many educators; nevertheless the extant research reveals different results in this regard.(Chuming, Ruiying, \& Xiaoxiang, 2000; Ferris, 1999; Ferris \& Roberts, 2001; Rahimi, 2009). Truscott $(1996,1999)$ is of the view that error feedback or grammar correction may harm the language learning skills of the students. Another research (Nusrat, Ashraf, Khan, Aziz, \& Jabeen, 2019), conducted in the Pakistani context concludes that indirect feedback improves learners' writing skills.

Although Pakistani secondary schools also keep experimenting with these pedagogical concepts depending on their institutional preferences, however, at university level, many students (despite having learnt English formally for 12 years) still lack proficiency in writing skills which calls for empirical research in this area.

\subsection{Reading-writing Connection}

During the last decade, however, many researchers explored the positive effects of repeated or fluent reading on Foreign Language learners' writing skills(Gorsuch \& Taguchi, 2008, 2010; Taguchi, Gorsuch, \& Sasamoto, 2006). With these developments, many private schools in Pakistan started introducing readers for improving students' proficiency in English in every class. 
UNIVERSITY OF CHITRAL JOURNAL OF LINGUISTICS AND LITERATURE

Lee (2005)asserts that free voluntary reading is the only significant predictor of improved foreign language writing performance. However, it is a common observation that only a few students are intrinsically motivated to read voluntarily unless they are majoring in the literature of that language. Hung and Young (2015)contend that the use of e-reader is a tool for reciprocal peer review facilitates the EFL students' process-based academic writing. We believe that acquiring fluency in any language requires a sufficient amount of input. This gives the idea that writing can be developed through reading and ESL teachers need to explore how they can introduce effective and purposeful reading activities in ELT classes.

Chen, Chen, and Sun (2010) propound that reading comprehension exercises are critical for developing strong writing skills of EFL learners. However, due to resource constraints, limited opportunities for English learners to collaboratively practice reading comprehension and lack of accurate evaluation methods, English instructors rarely assess students' literacy effectively. Young (1993) suggests that cognitively, students benefit more from reading authentic texts, having cultural information written in English, than from reading edited texts. Introducing authentic material has been found to be engaging and interesting as well. Su (2007)affirms that EFL learners appreciate if the instructor provides a wide range of authentic materials and class activities, and introduces tasks that allow students to interact with texts and each other in a flawless integration of the four language skills.

Many researches are in favour of linking reading with guided writing activities. Lightbown, Halter, White, and Horst (2002), for example, found that comprehensionbased learning left some particular gaps in the written language of students and concluded that there is need for pedagogical guidance for the development of writing skills. Lee and Schallert (2016) assert that an individual can learn to write by extensive reading as well as by extensive writing, as reading and writing both involve some of the same sub-processes. Yet, for improving writing, the reading-writing connection seems more evident for those second-language learners whose language proficiency exceeds a certain linguistic threshold. Though a component of all these is included in each class curriculum in Pakistan, the time constraint does not allow teachers to provide the students ample input purposefully. 
UNIVERSITY OF CHITRAL JOURNAL OF LINGUISTICS AND LITERATURE

VOL. 5 | ISSUE I | JAN - JUNE | 2021

ISSN (E): 2663-1512, ISSN (P): 26173611

Zhang (2017) maintains that both reading-writing integrated tasks and comprehensive corrective feedback improve overall language, content, and organization scores of EFL learners; and reading-writing integration tasks had a significant positive effect on language accuracy, content and language alignment.as well. Greene (1992) states that when students read to write, they do it with a sense of authorship, knowing that they will be expected to produce texts of their own, they use the source text as a heuristic for structuring and developing their own ideas. He is of the view that if students are to read in the role of writers, teachers need to give them opportunities to write, and to enter conversations. $\mathrm{Li}$ (2016)contends that in a reading-writing integrated situation, summarization tasks, EFL writing instruction and assessment for improvement in academic writing performance help develop the writing of learners. Tsou (2011) discovered significant improvements in most aspects of foreign language learners' writing proficiency, except for sentence structure after introducing Readers Theater (RT) for a whole semester. RT gives students a purpose to interact in class, to work with others, and to read and write for an audience. These are valuable insights that informed this research to link purposeful tasks with reading in order to improve learners' writing skills.

Reading and writing are both interlinked. They are structured arts and writing skill is not naturally acquired (Ellis, 2003). Interacting with each other, they create a text world, using the same cognitive structures (Greene, 1992). Reading plays a fundamental role in the development of the writing identity of the writer as Zigo, Derrico, and Paley (2009) assert. One becomes a writer if one reads like a writer (Smith, 1983). In L2 context, it is a common observation, too, that reading in the target language also equips the learners with the idiom of the target language by exposing them directly to input, thus helping them to produce fluent and accurate writing.Silva (2001) believes in bringing reading systematically into writing classrooms, considering reading and writing both as active construction of meaning reciprocally. The text can be read with varying degrees of attention since comprehension of each section is not necessary. The significance of the main ideas and details becomes clearer as the student determines which ones further his or her purposes. This helps build schemata which, in turn, helps them is writing texts on similar topics. 
Despite these facts, writing skill has traditionally been downgraded to homework in L2 teaching due to time constraint, thus limiting the possibility of teacher guidance. In Pakistan, a similar practice has been in vogue till recently. This was because, as Escribano (1999) suggests, language was not considered a two-way tool with which a writer and a reader communicate and the content usually comprised of selected written texts followed by some explanation of particular vocabulary items, different grammar and vocabulary related exercises and comprehension questions, focusing on accuracy rather than fluency. The students required to create error-free text without giving any preference to the meaning of the finished product faced numerous hurdles as they were basically "writing to learn and not learning to write" (Tribble, 1996)in this traditional product-oriented approach.

\subsection{Process-Centred Approach and Task-based Teaching}

Process approaches have been accepted in ESL/EFL composition because of their two main elements: awareness and intervention (Susser, 1994). Language learning is a developmental process that promotes communication rather than acquisition of a product by practising grammar items (Jeon \& Kaya, 2006) as in the Presentation, Practice, Production (PPP) approach propounded by communicative methodology of language teaching. Thus, effective language learning can be ensured by exposing learners to meaningful task-based activities with a focus on process rather than product (Acar, 2006).

Task-based language teaching features a need-based content selection; introducing authentic texts with opportunities for learners to focus on language and the learning process; focus on communication in the target language; and learners' experiences taken as important contributions to classroom learning and connecting classroom learning with performance outside the classroom (Nunan, 2006). As Nunan (2004) defines it, a task is a piece of classroom work involving learners to comprehend, manipulate, interact or produce in the target language with their attention on utilizing their grammatical knowledge to express meaning, focusing more on expressing meaning rather than manipulating form. Ellis (2003) defines a task as a work plan requiring learners to pragmatically process language to achieve an outcome assessable in terms of real-life usage. It can employ various cognitive processes and skills. 
Willis and Willis (2001) propound that contrary to grammatical exercises, tasks give learners freedom to use a variety of language structures to achieve outcomes without specifying forms in advance. As Heffernan (2006) has it, writing in English requires expository style which includes an introduction having a thesis statement, followed by paragraphs having topic sentences, and examples that support the thesis, and a logical conclusion, students in the present study were given tasks to ensure that they notice these patterns in the structures of the essays and texts they read.

Escribano (1999) claims that text analysis and comparison of text characteristics help to build the schemata for writing practice. Students need to be familiar with different discourse functions through extensive reading in order to be able to produce clear pieces of writing because clarity and comprehension are facilitated when writers take care of the readers' expectations regarding the structure, content, development, organization and graphical appearance of texts. Thus, a synthesis of writing and reading can be a model for teaching writing proficiency aiming at fluency, along with accuracy just as Escribano (1999) proposes combining the objectives for teaching reading e.g., identifying the type of writing and its structure, locating main ideas, facts and logical connectors, deducing meaning and implied information and summarizing points and objectives of teaching writing e.g., writing clear paragraphs with a knowledge of topic sentence, using connectors and discourse markers, and keeping textual coherence in English courses.

Although the connection between reading and writing has been acknowledged by many researchers, there is dearth of research on practical application of this relationship. The present study is an attempt to bridge the gap between the theoretical proposition of this link and empirical classroom research. We assume that when tasks are associated with the reading material introduced in class, they give a purpose to learners and also help learners to focus on the details required in order to be better L2 writers.

\subsection{Rationale}

\section{Methodology}

This quantitative, action research was prompted by the participating students' need to be better academic writers in the course of a semester i.e., 4 months. We felt 
that the undergraduate ESL learners from Pakistan, with computer science as their major, should be trained for writing better in the target language through a lot of practice in authentic reading texts from local as well as international sources i.e., English texts produced by non-native and native users of English. Tasks were associated with these authentic texts in order to provide the students with external motivation of having a purpose to read the texts with a focus. It also gave opportunity for teacher guidance and helped learners notice the details in texts that they needed to in order to utilize them while writing.

\subsection{Research Design}

This intervention based, qualitative research was carried out on two groups of undergraduate students studying in Bachelor of Computer Science at COMSATS University Islamabad, Lahore Campus. According to the university curriculum, all undergraduate students have to study a module in English titled English Comprehension and Composition as a compulsory requirement in Semester 1. This module focuses on teaching all the four skills of reading, writing, listening and speaking. The purpose of the module is to prepare students for academic and professional communication in their programs of study and professionally after graduation. Prior to this, at secondary school level, students are provided practice in essay writing, letter writing and paragraph writing.

The study followed a pre- and post- test design in which students were required to write essays before and after the intervention. The first researcher conducted the preand post- tests and the instruction and intervention. The data were collected from two undergraduate classes on two stages of a semester. The total number of students in both the sections was 36. They had a background of 12 years of learning English as a Second Language at school and college level. Their ages ranged from 18 to 20 with a mean of 19 years and standard deviation of 0.66 . In the beginning of the semester, composition writing was introduced for the first time in class using tradition lecturing on what an essay is and how it needs to be written and as a pre-test they were made to write an essay. Afterwards, the participants were exposed to a lot of reading material with taskbased activities during classes. At the end of the semester, they were required to write an essay on another topic as post-test. 
UNIVERSITY OF CHITRAL JOURNAL OF LINGUISTICS AND LITERATURE

\subsection{Setting}

There were 31 students who appeared for the post-test. Hence, for comparison purposes, we analysed the pre-tests and post-tests of only those 31 students who appeared for both pre- and post- tests. In this study, we used the tasks with a focus on meaning, considering grammar as a tool to express meaning as Nunan's definition (Nunan, 2004, 2006)referred to in Section 2.3 above suggests. Moreover, since the participants of our study had had exposure to Grammar for 12 years prior to studying this module, it was assumed that they have sufficient grammar knowledge to express meaning. Therefore, the focus of tasks was to expose them to a variety of input material in the target language in order to equip them with a reasonable amount of fluency required to produce similar pieces of writing and also to examine whether this exposure also improves the form that they use in post-tests as an added advantage.

For pre-test, both the classes were required to write a composition after traditional lecturing, discussion and brainstorming about what a composition consists of and how it should be written. Once they had written the compositions, the compositions were evaluated.

Three neutral evaluators from the Department of English were hired to evaluate the pre-tests and post-tests. To provide the evaluators a uniform standard for grading, the writing proficiency of these participants and to minimize subjectivity in assessment, we adapted the Abington Grading Standards for Writing to suit the purpose of the present study in its context. Each item of the rubric that was to be marked in the test was explained to students before each test. The items were: (1) content, (2) organization, (3) sentence structure (SS), (4) diction, and (5) grammar, punctuation and spelling (GPS). Each item was allotted scores from 1-4 to rate performance, with the maximum score on each item being 4 and the total score being 20 for the composition if written flawlessly.

To maintain impartiality in evaluation, participants' names were removed from the scripts and they were numbered 1 to 31 . The three evaluators were brainstormed in detail about the rubric. They assessed the participants' work accordingly. The average of the scores given by three evaluators was used in order to minimize the unobserved interpersonal heterogeneity. The average scores were normalized so that they ranged between 0 (worst performance) and 4 (best performance). 
After the pre-test, the learners were exposed to specific reading material similar to the ones they were supposed to produce in writing during the semester e.g., essays, paragraphs, letters, reports and paragraphs meant for comprehension; and a variety of tasks (given in Table 1) were devised to be given with each reading material. The purpose was to ensure students' in-depth understanding of the text through analyzing, brainstorming, skimming, scanning, previewing, critiquing, etc. While devising the tasks, the focus was to drive students' attention to content and the final product i.e., overall fluency rather than the form or grammar utilized. The purpose was to test whether they also pay attention to form when reading to comprehend the meaning which would improve both form and meaning gradually till they appear for the post tests.

Frequent exposure to task-based reading material followed by purposeful tasks was incorporated into the existing English Comprehension and Composition module's syllabus and was introduced three hours per week during the sixteen-week semester.

\subsection{Types of Texts and Tasks Introduced in Class}

The texts were taken fromarticles and editorial sections of the most widely read dailies including Dawn and the News, CSS (Central Superior Services) Examination papers from the past and reading comprehension passages and sample candidates essays from IELTS Examination.The texts given to the students are considered to reflect a wide variability in terms of the quality of the language, effectiveness of communication, and level of academic rigor. As an illustration, there is a wide diversity in the quality of letters to the editors. Sometimes seasoned writers and journalists voice their concerns through the letters to the editor. However, mostly the amateur writers express their ideas through these letters. The quality of the local newspapers is also not uniform. Newspapers like Dawn and The News are generally considered to be the best, followed by Tribune and other English-language regional newspapers.

In Pakistan's educational system, the CSS examination is considered to be the most challenging and rigorous. As the minimum threshold is 14 years of education, many candidates for this examination may only have average language skills. However, given the prestige that goes with passing this examination, and the privileges that employees in the CSS cadre enjoy, the best and the brightest candidates also are 
attracted to this examination. Consequently, most of the essays in the popular essay collections/books may be of general interest and are written in simple language. However, in some cases, the essays may be very technical and require advanced language skills to understand them. The sample CSS essays given to the students for practice may reflect an above average level of English language comprehension.

The participants were also given a lot of other essays to read on their own and were also encouraged to find and read more on their own for building a huge schema for writing.

Tasks introduced after different reading texts ranged from the comprehension sub skills including skimming, scanning, previewing, and predicting to summarizing and overall understanding and evaluation of the texts read. These were in line with the recommendations of Escribano, 1999; Lightbown, Halter, White, and Horst (2002),Ahmed \& Rajab 2015; Chen, Chen, and Sun (2010).For teaching an in-depth understanding of the content and structure of the text introduced, they were asked to locate the topic sentence of given paragraphs. After making them read candidates' sample essays from past papers of IELTS, they were asked to locate the strengths and weaknesses of the essays, main errors, and also to grade them and tell what they would have added to the essay had they written it. A few essays were introduced as comprehension tasks and they were asked to find facts and opinions, infer something on the basis of their reading; comment on the author's point of view and add their own; write the gist or main theme of the text; summary and rephrase some specific information.

Table 1 shows a list of the types of texts introduced and related tasks students were involved in.

Table 1: Types of texts and tasks introduced in class

\begin{tabular}{clll}
\hline $\begin{array}{l}\text { Types } \\
\text { Introduced }\end{array}$ & Authentic & Texts & Types of Tasks \\
\hline $\begin{array}{c}\text { 1. Articles from } \\
\text { newspaper }\end{array}$ & local & Skimming \\
\hline $\begin{array}{c}\text { 2. } \\
\text { newspapers }\end{array}$ & Sctters to editor from local & Scanning \\
\hline $\begin{array}{l}\text { 3. } \quad \text { Reading comprehension } \\
\text { passages from IELTS }\end{array}$ & $\begin{array}{l}\text { Previewing i.e., guessing the contents } \\
\text { of a piece of writing by just reading } \\
\text { its title }\end{array}$ \\
\hline
\end{tabular}


UNIVERSITY OF CHITRAL JOURNAL OF LINGUISTICS AND LITERATURE

4. Samples of good and not so good essays written by candidates for IELTS Writing test (with bands ranging from 6 to 7 ) and followed by their critical analysis by learners

5. Samples of essays for CSS Competitive examination Pakistan followed by analytical questions

Locating topic sentence in a given paragraph

1) Giving a title to a piece of writing after reading it

2) In pairs, reading 5 different essays from IELTS sample papers and answering the following:

a) Analyze the main elements/features of the essay

b) Discuss its strengths/weaknesses

c) Point out the errors or areas for improvement

d) What would you have added had you written the essay?

e) What grade would you give to the essay?

3) Twenty different types of comprehension questions based on 5 different essays based on

a) Fact finding

b) Locating opinion

c) Inferences

d) Straightforward

e) Commenting on the author's stance

f) Adding their own point of view on the same topic

g) Writing the main theme

h) Writing a summary

i) Rephrasing certain information

At the end of the semester, a post-test was conducted which required the participants to write an essay on another topic. They were given three topics with a choice to write on any one of them. The essays written by the participants were evaluated again by the same evaluators. Again, the average scores were calculated.

The scores of the pre-test and post-tests were then analyzed using pairedsample Wilcoxon signed rank test. Wilcoxon signed rank test compares the mean ranks of the two scores in pre and post-test(Gehan, 1965; Woolson, 2007). Since the variance of the scores of the students could also differ, we used t-test with Satterthwaite 
UNIVERSITY OF CHITRAL JOURNAL OF LINGUISTICS AND LITERATURE

approximation to compare the scores of the students in the pre- and post-test period assuming unequal variance in the scores across both groups. The null hypothesis in case of two groups with unequal variances is that the two variances are different(De Winter, 2013; Zimmerman \& Zumbo, 1993).

\section{Results and Discussion}

Descriptive summary statistics of the five study variables namely (1) content, (2) organization, (3) sentence structure (SS), (4) diction, (5) grammar, punctuation and spellings (GPS) as well as the test statistics comparing the pre-test and post-test performance of the students are given in Table 2.

Table 2: Summary Statistics and Wilcoxon Signed Rank Test

\begin{tabular}{|c|c|c|c|c|c|c|c|c|c|c|c|c|}
\hline & & & & & & & & \multicolumn{2}{|c|}{ Wilcoxon signed rank test } & \multicolumn{3}{|c|}{ T-test assuming unequal variance } \\
\hline & Period & Obs & Mean & SD & Min & Max & Z & $P$ & $\mathrm{df}^{*}$ & t-value & p_value & \\
\hline \multirow[t]{2}{*}{ Content } & Pre-test & 31 & & 2.914 & 0.63 & 1.67 & 4.00 & 2.589 & 0.096 & 58.672 & 2.8289 & 0.0064 \\
\hline & Post-test & 31 & & 3.333 & 0.54 & 2.33 & 4.00 & & & & & \\
\hline \multirow[t]{2}{*}{ Organization } & Pre-test & 31 & & 3 & 0.57 & 2.00 & 4.00 & 2.850 & 0.0044 & 56.7322 & -3.2203 & 0.0021 \\
\hline & Post-test & 31 & & 3.42 & 0.45 & 2.67 & 4.00 & & & & & \\
\hline \multirow[t]{2}{*}{ SS } & Pre-test & 31 & & 2.688 & 0.71 & 1.33 & 3.67 & -4.292 & 0.0000 & 46.627 & -5.2504 & 0.000 \\
\hline & Post-test & 31 & & 3.451 & 0.39 & 2.67 & 4.00 & & & & & \\
\hline \multirow[t]{2}{*}{ Diction } & Pre-test & 31 & & 2.623 & 0.63 & 1.33 & 3.67 & -2.754 & 0.0059 & 57.0138 & -3.0032 & 0.0040 \\
\hline & Post-test & 31 & & 3.054 & 0.50 & 2.00 & 4.00 & & & & & \\
\hline \multirow[t]{2}{*}{ GPS } & Pre-test & 31 & & 2.494 & 0.61 & 1.00 & 3.33 & -4.180 & 0.0000 & 52.3129 & -4.7855 & 0.000 \\
\hline & Post-test & 31 & & 3.129 & 0.41 & 2.33 & 3.67 & & & & & \\
\hline
\end{tabular}

* Satterthwaite's degrees of freedom

Comparing the baseline scores in the pre-test period suggests that students performed best in organization with a mean score equal to 3 out of a maximum of four and performed worst on GPS with the mean score equal to 2.49. A look at the minimum marks across all five indicators shows that the worst performance was in GPS with the minimum score equal to 1 . The maximum score is 4 (out of four) in content and organization.

The Wilcoxon signed rank test which compares the mean ranks of the two scores in pre and post-test shows that students made a statistically significant improvement in all five parameters $(\mathrm{P}<0.01)$. Since the minimum and maximum marks in both the periods are not similar, we additionally used t-test using Satterthwaite's approximation which assumes unequal variance in two groups. The t-test also shows that students made a statistically significant improvement in all the parameters $(\mathrm{P}<$ $0.01)$.

The difference in the average scores in the two periods across the five parameters is not uniform. The largest improvement in the mean scores in the pre- and 
UNIVERSITY OF CHITRAL JOURNAL OF LINGUISTICS AND LITERATURE

post- treatment is in SS (28.25\%) followed by GPS (25.70\%). Change in the score from pre-test to post-test in content, organization and diction was relatively smaller than SS and GPS, and nearly similar otherwise $(14.4 \%, 14.0 \%$ and $16.41 \%$ respectively). Our findings are consistent with some previous studies like Lee and Schallert (2016), Escribano (1999), Li (2016) and Zhang (2017) in proving that extensive reading especially when linked with purposeful tasks improves ESL learners' writing.

A $28 \%$ increase in the SS score is a little surprising because the English and Urdu sentence structures differ widely. Urdu follows a Subject-object-verb order and English follows a subject-verb-object order if we talk of the simplest and the most basic structure e.g., the Urdu sentence:

Usne mujhe English parhai.

|Subject| |object| |Object| |Verb|

which when translated word-for -word in English would look like:

He me English taught.

instead of the English structure

He taught me English.

|Subject| | Verb | |Object| | object |

At the pre-test stage, students with the grammar translation method background were, arguably, more heavily influenced by the structure of Urdu sentences than the English sentences. What these students lacked was input in the target language through a direct method which was provided during intervention for this study and also made purposeful by introducing tasks related to the texts introduced. Exposure to a huge amount of authentic reading material along with tasks helped them overcome the first language interference as far as sentence construction is concerned(Krashen, 1985; Willis \& Willis, 2001). Intensive reading also equipped them with the fluency required in sentence construction in the target language without referring to grammatical rules working behind them(Su, 2007).

Given the smallest mean score in GPS in the pre-test period, more than $25 \%$ improvement in the GPS mean score in the post-test is encouraging. This supports our assumption that when focusing on details required by the tasks introduced like locating specific information, writing the gist, finding errors and point out areas of improvement 
UNIVERSITY OF CHITRAL JOURNAL OF LINGUISTICS AND LITERATURE

VOL. 5 | ISSUE I | JAN - JUNE | 2021

ISSN (E): 2663-1512, ISSN (P): 26173611

in the given texts, the learners will also notice the form and structure of the text as an added advantage and will be able to reproduce them in their own L2 writing (Willis \& Willis, 2001). This also implies that this component of a FL or $2^{\text {nd }}$ language does not necessarily require explicit pedagogical instruction at undergraduate level if the instructor introduces sufficient amount of input in the form of reading material in a taskbased milieu (Zhang, 2017).Task- based reading can thus provide a quick solution to the needs of the students under study who have limited proficiency but require to achieve a good level of proficiency in one semester in order to be able to study the advanced courses of technical English in Next semesters and for other subjects also whose medium of instruction is English.

\section{Conclusion}

The findings of the study suggest that excessive exposure to reading material in the target language through task-based activities has a positive effect on the writing performance of ESL learners. The study recommends that ESL instructors must include task-based activities as a compulsory component of their teaching methodology in order to improve the writing efficacy of the learners. Keeping in view the limited time available in a semester for improving writing, task-based approach can prove to be a good strategy to expose learners to maximum possible target language input, and thus, ensure a quick improvement in performance. For maximizing input, flipped learning can also be sometimes utilized (Aziz, et al.2021) such that the reading material is given for home and the activities and tasks are introduced in class. Though task-based teaching is strongly recommended as a big portion of any writing module, it should be accompanied with other activities or material specifically meant to enhance the diction and grammatical competence of the learners e.g., the tasks related to finding errors in the given text samples and asking them to improve upon them proved very effective during this study. Similarly, reading authentic texts and writing their gist or summary and interpreting the writer's stance turned out to be very productive. This study, therefore, attempts to prove that teaching writing through task-based reading is an important pedagogical instrument for the development of academic writing performance of second language learners. It also recommends adding ample reading material as an essential and substantial component of syllabus wherever EFL/ESL pedagogy is done in 
the world to better equip the learners with the skill required in other subjects of the curriculum and research, too i.e., writing.

\section{References}

Abington

grading

standards

for

writing.http://abingtonsports.com/documents/2014/9/3//Grading_Standards_for_ Writing_1.pdf?id=487 Retrieved on 11.12.2014.

Acar, A. (2006). Models, norms and goals for English as an international language pedagogy and task based language teaching and learning. Asian EFL Journal, $8(3)$.

Ahmed, R. A. I., \& Rajab, H. (2015). Enhancing elementary level EFL students' reading comprehension and writing skills through extensive reading enrichment program. International Journal of English Language Education, 3(2), 2015. doi:10.5296/ijele.v3i2.7742

Aziz, S., Imtiaz, A., Shahzad, A. K., \& Amir-ud-Din, R. Twisting the Class: Are we ready for a Flipped ESL Classroom? Turkish Online Journal of Qualitative Enquiry,12(9), 3827-3837.

Chen, J.-M., Chen, M.-C., \& Sun, Y. S. (2010). A novel approach for enhancing student reading comprehension and assisting teacher assessment of literacy. Computers \& Education, 55(3), 1367-1382. doi:10.1016/j.compedu.2010.06.011

Chuming, W., Ruiying, N., \& Xiaoxiang, Z. (2000). Improving English through writing. Foreign Language Teaching and Research, 3. de Carvalho, I. F., \& Briglia, T. M. (2013). The Shakespearean dramatic text in the English class in Brazilian high school.doi: 10.4013/cld.2013.113.09

Ellis, R. (2003). Task-based language learning and teaching: Oxford University Press.

Escribano, P. D. (1999). Teaching writing through reading: a text-centred approach. Ibérica, Revista de la Asociación Europea de Lenguas para Fines Específicos(1), 55-62.

Ezza, E.-S. (2010). Arab EFL learners' writing dilemma at tertiary level. English Language Teaching, 3(4). 
Ferris, D. (1999). The case for grammar correction in L2 writing classes: A response to Truscott (1996). Journal of second language writing, 8(1), 1-11. doi:10.1016/S1060-3743(99)80110-6

Ferris, D., \& Roberts, B. (2001). Error feedback in L2 writing classes: How explicit does it need to be? Journal of second language writing, 10(3), 161-184. doi:10.1016/S1060-3743(01)00039-X

Gorsuch, G., \& Taguchi, E. (2008). Repeated reading for developing reading fluency and reading comprehension: The case of EFL learners in Vietnam. System, 36(2), 253-278. doi:10.1016/j.system.2007.09.009

Gorsuch, G., \& Taguchi, E. (2010). Developing reading fluency and comprehension using repeated reading: Evidence from longitudinal student reports. Language Teaching Research, 14(1), 27-59. doi:10.1177/1362168809346494

Greene, S. (1992). Mining texts in reading to write. Journal of Advanced Composition, 151-170.

Heffernan, N. (2006). An integrated approach to teaching academic writing. Asian EFL Journal, 8(3).

Huang, B. H., \& Bailey, A. L. (2016). The long-term English language and literacy outcomes of first-generation former child immigrants in the United States. Teachers College Record, 118(11).

Hung, H.-C., \& Young, S. S.-C. (2015). The effectiveness of adopting E-readers to facilitate EFL students' process-based academic writing. Journal of Educational Technology \& Society, 18(1), 250-263.

Hosseinpour, N., \& Biria, R. (2014). Improving Iranian EFL learners' writing through task-based collaboration. Theory and Practice in Language Studies, 4(11), 24282435. doi:10.4304/tpls.4.11.2428-2435

Jeon, E. H., \& Kaya, T. (2006). Effects of L2 instruction on interlanguage pragmatic development. Synthesizing research on language learning and teaching, 165, 211.

Kafipour, R., Mahmoudi, E., \& Khojasteh, L. (2018). The effect of task-based language teaching on analytic writing in EFL classrooms. Cogent Education, 5(1), 1496627. doi:10.1080/2331186X.2018.1496627 
Lee, J., \& Schallert, D. L. (2016). Exploring the reading-writing connection: A yearlongclassroom-based experimental study of middle school students developing literacy in a new language. Reading Research Quarterly, 51(2), 143164. doi:10.1002/rrq.132

Lee, S. y. (2005). Facilitating and inhibiting factors in English as a foreign language writing performance: A model testing with structural equation modeling. Language learning, 55(2), 335-374. doi:10.1111/j.0023-8333.2005.00306.x

Li, J. (2016). Modeling the process of summary writing of Chinese learners of English as a foreign language. Irish Educational Studies, 35(1), 73-100. doi.org/10.1080/03323315.2016.1146154

Lightbown, P., Halter, R., White, J., \& Horst, M. (2002). Comprehension-based learning: The limits of 'do it yourself'. Canadian Modern Language Review, 58(3), 427-464. doi: 10.3138/cmlr.58.3.427

Negari, G. M. (2011). A study on strategy instruction and EFL learners' writing skill. International journal of English linguistics, 1(2), 299. doi:10.5539/ijel.v1n2p299

Nunan, D. (2004). Task-based language teaching: Ernst Klett Sprachen.

Nunan, D. (2006). Task-based language teaching in the Asia context: Defining'task'. Asian EFL Journal, 8(3).

Nusrat, A., Ashraf, F., Khan, S., Aziz, S., \& Jabeen, R. (2019). Is Indirect Written Feedback Valuable? A Study Targeting ESL University Students in Pakistan. International Journal of English Linguistics, 9(5). doi:10.5539/ijel.v9n5p340

Rahimi, M. (2009). The role of teacher's corrective feedback in improving Iranian EFL learners' writing accuracy over time: is learner's mother tongue relevant? Reading and Writing, 22(2), 219-243.doi:10.1007/s11145-008-9139-5

Rahman, T. (2019). Mother tongue education policy in Pakistan. The Routledge international handbook of language education policy in Asia, 364-381.

Shaheen, U., Rafi, M. S., Aziz, S., \& Ain, N. U. (2019). Meeting Diversity in ESL Classroom: A Pedagogical Model for a Globalized Milieu. The Journal of Teaching English for Specific and Academic Purposes,7(2), 237-253. https://doi.org/10.22190/JTESAP1902237S 
Silva, T. (2001). Toward an understanding of the distinct nature of L2 writing: The ESL research and its implications. Landmark essays on ESL writing, 191-208. https://doi.org/10.2307/3587400

Smith, F. (1983). Reading like a writer. Language arts, 60(5), 558-567.

Su, Y.-C. (2007). Students' changing views and the integrated-skills approach in Taiwan's EFL college classes. Asia Pacific Education Review, 8(1), 27-40. doi.org/10.1007/BF03025831

Susser, B. (1994). Process approaches in ESL/EFL writing instruction. Journal of second language writing, 3(1), 31-47. https://doi.org/10.1016/10603743(94)90004-3

Taguchi, E., Gorsuch, G. J., \& Sasamoto, E. (2006). Developing second and foreign language reading fluency and its effect on comprehension: A missing link. Reading Matrix: An International Online Journal, 6(2).

Tribble, C. (1996). Writing Oxford University Press.

Truscott, J. (1996). The case against grammar correction in L2 writing classes. Language learning, 46(2), 327-369. doi.org/10.1111/j.14671770.1996.tb01238.x

Truscott, J. (1999). The case for "The Case Against Grammar Correction in L2 Writing Classes": A response to Ferris. Journal of second language writing, 8(2), 111122. doi:10.1016/s1060-3743(99)80124-6

Tsou, W. (2011). The application of readers theater to FLES (Foreign Language in the Elementary Schools) reading and writing. Foreign Language Annals, 44(4), 727-748. doi.org/10.1111/j.1944-9720.2011.01147.x

Willis, D., \& Willis, J. (2001). Task-based language learning The Cambridge Guide to Teaching English to Speakers of Other Languages (pp. 173-179): Cambridge University Press.

Yundayani, A., Ezmir\& Rafli, Z. (2018). Yundayani, A., \& Rafli, Z. The Effectiveness of Task-Based Instructional Materials on Students' Writing Skills for Academic Purposes.International Journal of English and Education.7(1), 1-10 
UNIVERSITY OF CHITRAL JOURNAL OF LINGUISTICS AND LITERATURE

VOL. 5 | ISSUE I | JAN - JUNE | 2021

Young, D. J. (1993). Processing strategies of foreign language readers: Authentic and edited input. Foreign Language Annals, 26(4), 451-468. doi:10.1111/j.19449720.1993.tb01180.x

Zhang, X. (2017). Reading-writing integrated tasks, comprehensive corrective feedback, and EFL writing development. Language Teaching Research, 21(2), 217-240. https://doi.org/10.1177/1362168815623291

Zigo, D., Derrico, R. D., \& Paley, N. (2009). Book Walk: Works That Move Our Teaching Forward: Developing Personal Literacies: Writing through Reading. English Education, 41(2), 177-186.

\begin{tabular}{|l|l|}
\hline CC) & $\begin{array}{l}\text { @ } 2021 \text { by the author. Licensee University of Chitral, Journal of } \\
\text { Linguistics \& Literature, Pakistan. This article is an open access } \\
\text { article distributed under the terms and conditions of the Creative } \\
\text { Commons Attribution } \\
\text { (http://creativecommons.org/licenses/by/4.0/). }\end{array}$ \\
\hline
\end{tabular}

